\title{
Poetry as a Deep Emotional Experience of a Different World: The Example of Goethe's West-Eastern Divan
}

\author{
Ottmar Fuchs \\ Faculty of Catholic Theology, Department of Practical Theology, Eberhard-Karls-University, Tuebingen, Germany
}

\section{Email address:}

ottmar.fuchs@uni-tuebingen.de

\section{To cite this article:}

Ottmar Fuchs, Tübingen, Lichtenfels, Germany. Poetry as a Deep Emotional Experience of a Different World: The Example of Goethe's West-Eastern Divan. International Journal of Language and Linguistics. Vol. 5, No. 6, 2017, pp. 172-178. doi: $10.11648 /$ j.ij1l.20170506.12

Received: September 30, 2017; Accepted: October 23, 2017; Published: November 16, 2017

\begin{abstract}
Poetry which comes from other religions and cultures can become an emotionally based bodily experience of a different world. This way of accessing the Other breaks down the biogenetic fixation on one's own pack, family and land, and the concomitant hatred of strangers - other people, tribes and nations. This happens within an aesthetic context where we do not feel threatened and engage in the transition playfully and imaginatively. Currently, questions about the possibility of shared spaces enabling inter-cultural and inter-religious co-existence are of great importance. How does Goethe deal with what he finds in that alien world of poems by the Persian poet Hafiz? Goethe's West-Eastern Divan may be considered an excellent role model of intercultural learning, centred on a training in aesthetically based empathy.
\end{abstract}

Keywords: Intercultural Coexistence, Interreligious Communication, Linguistic Empathy, Poetic Assimilation, Aesthetic Identification

\section{Introduction [1]}

Literature creates an imaginative space where acts of identification with other realities become possible. On the one hand, the literary text is a blueprint whose characters and stories guide our emotional reactions, but on the other, much space is left for us to elaborate them creatively within our own affective setting, in ways that enrich our imagination. Patrick Colm Hogan suggests that different cultural expressions are rooted in an emotional constitution shared universally by all humans: Reading literature and philosophy from other traditions is not ... a matter of looking at different icons, at other selves and social relations. It is the same icon all along, the same human self and the same human relations. But through the various traditions, that icon is loosed from its fixed place, lifted from behind a glass, as if I could now turn it in my hand and examine it from a different angle. [2]

If that literature comes from other religions and cultures, from unfamiliar social strata and personal backgrounds, there is a correlation, and a mutual enrichment, between literary competence and intercultural competence. If we empathize with a fictional character, we at the same time empathize with the cultural community represented by him or her.
Empathizing with a real or fictional person is a means of inhibiting aggression and violent responses. [3]

This way of accessing the Other breaks down the biogenetic fixation on one's own pack, family and descendants, and the concomitant hatred of strangers - other people, tribes and nations. This happens within an aesthetic context or conversation where we do not feel threatened and engage in the transition playfully and imaginatively.

On account of how it operates poetically, Goethe's WestEastern Diwan may be considered an excellent role model of intercultural learning, centred on a training in empathy, so to speak. The path offered here is that of imitation, or taking on a role or attitude by imitation through play, acting or stage drama, analogous perhaps to experimental archaeology. In order to understand the meaning of the Muslim prayer position as a physical expression of reverence for God, we must experience it through our own bodies.

Currently, questions about the possibility of shared spaces enabling inter-cultural and inter-religious co-existence are of great importance and here Johann Wolfgang von Goethe's West-Eastern Diwan [4] is interesting to me in two respects: 
firstly, on account of its poetical hermeneutics of that alien world of poems by the Persian poet Hafiz, and secondly, on account of how it deals with what it finds in that alien world.

Mahomet: a genius?

Goethe's first attempt at tackling the Mahomet material dates from 1773. Many years later, looking back as he is writing his Poetry and Truth in 1814, he talks of his intention of using the example of Mahomet to explore the general patterns of a great character and a great mind: What is heavenly and eternal becomes embodied in earthly intentions and is swept away towards a transient fate. [5] Goethe writes: Just prior to that, I had taken a great interest in, and done much reading about, the life of the oriental prophet, and thus I was fairly well prepared when the thought occurred to me.... Everything that genius can do to humans by way of the character and the mind was to be depicted, and all the ways it gains and loses in the process. [6]

In opposition to the Enlightenment's preference for rationalisation, Goethe enters here the storm and stress of empathy, feelings and emotions, of a world that reason cannot comprehend. [7] Thus he has Mahomet say: Do you not see him? In every still spring, under every blossoming tree I encounter him in the warmth of his love. How grateful I am: he has opened my breast and softened the hard shell of my heart, so that I can feel his approach. [8] The importance of this particular image to him is shown by his wish, articulated in a 1772 letter to Herder: Oh may I pray like Moses in the Qur'an: Lord, create a space in the tightness of my breast. [9] (see Sura XX).

The God experienced by Goethe's Mahomet is manifest in genius, in the person of genius, in the stream of genius that flows from the spring in the rock, complete with all its tributaries, into the ocean of eternity. [10] Neverending creativity takes the genius (including the religious genius) into a realm where boundaries are transcended, into the divine infinity, symbolised in this instance by ,father' ocean. [11] Thus Goethe focuses on the charismatic prophet Mahomet and claims him as an example of a person of genius that is particularly impressive, not least due to his intriguing otherness. This situates him in the context of the genius-debate of his time. [12]

This maneuver yields an enormous gain in tolerance. Interreligious boundaries and fixed categories are broken down by being understood and conveyed against the backdrop of the universal human drama of the genius. From a structuralanalytical point of view, we could say that Goethe appreciates in the Other what he admires in the familiar. Thus, Goethe discovers what is good and familiar in what is alien and other, and he expresses his approval - the price being the Other's having to submit to this pattern. This, therefore, is the mechanism that facilitates a connection with a limited pluralism of people in diverse religions and cultures.

\section{Method}

Poetic appropriation
The issues featuring in Goethe's dislike of Voltaire's image of Mahomet will resurface with a vengeance for the ageing poet when, in 1814, he encounters the Diwan, the collection of poems by the Persian poet Hafiz, the German translation of which was published a year earlier. [13]

In encountering the Persian poet, Goethe enters into yet another new and different relationship with the Other: on the level of shared poetry. This is the hermeneutics of appropriation, of poetic empathy. Goethe now goes further than he did before: No longer does Mahomet serve as a foil onto which to project a European concept of genius; between 1814 and 1819 there occurs a kind of abandonment of one poet to another poet, with the encounter including elements of self-surrender. Conrady talks of a creative event in discussing the fact that in the seventh decade of his life, Goethe produced such lyrical richness, and was able to develop a new lyrical language. [14]

Goethe's poetical path between two worlds is reflected in his explanation of three distinct approaches to translation: The first one aims to familiarise us with a foreign country, and for this, a simple and prosaic approach is the best. The second approach involves aiming to transpose ourselves into the circumstances of the foreign country, but is actually just a grasping what is foreign and representing it in our own terms. The highest form of translation, however, occurs where we seek to make the translation identical with the original, so that the one may stand, not instead of the other, but in place of the other. This approach was initially met with the biggest resistance, because the translator who commits himself firmly to his original virtually gives up his own nation's originality, and thus a third entity comes into being, and the masses need time to develop a taste for this. [15] To hear Goethe talk of the one taking the place of the other is at first slightly startling. However, he does not envisage the familiar replacing the Other; the dynamic he addresses is the reverse: namely, that the Other may live and flourish in the familiar that is given up. For the resistance originates from the fact that the originality of what is one's own is given up, so that a sort of surrender occurs of the familiar to the Other. This is what generates a third entity, for which according to Goethe most people still lack a sense. However, feeling meaning in the Other is just what is at stake for Goethe. [16]

So Goethe does not want to be simply a receptive reader, he wants to respond productively and take part in the Persian writer's poetry. The only way of doing so is through a poetic mirroring of his poetry, through an imitatio - not in the superficial sense of the word but in the sense of a behavioural hermeneutics, analogous to a behavioural therapy where it is by way of behavioural change, and not chiefly via analysis, that understanding is achieved.

Thus, experience through imitation is not a superficial copying but a deep, emotional comprehension of another reality that encompasses our own existence entirely. Even what is not understood rationally can be the object of such imitation, in the sense of a physical understanding, an embodied feeling of a reality. And this is possible at any age, with nursery-age children, or with the mentally disabled. 
Some things cannot be understood, but can be intimated through action, and then reason may follow, as best it can. In order to understand the meaning of the Muslim prayer position as a physical expression of reverence for God, we must experience it through our own bodies. Life is like this: a gift through birth, it is not until later that it is understood; an experience of meaning, or of its opposite, occurs later in connection with the gift of embodied life.

In the same way, small infants have to take food and drink by blind faith to survive. The body needs itself prior to rational understanding and control. Every human being is dependent on this sense of basic trust in order to survive and live. There is no reason not to apply this principle of basic trust in other areas, for example in empathising with others' experiences, cultural and religious customs etc. The experience shows the same structure in each case, centred as it is around an unreserved embracing of a reality and being held in it.

The idea of promise can be applied here as well: we enter into something Other without a prior understanding or experience of it. Any inter-cultural or inter-religious encounter always involves such a deferment of gratification. This secondary transfer of our sense of basic trust should become a habitual advance, in analogy to a culture of hospitality where an openness is shown to the physical and spiritual needs of the visitor without knowing him or her beforehand.

It is a kind of experimental archaeology in that there is a putting-into-practice, through experiment, of ways of living and experiencing that stem from the past (in archaeology) or from elsewhere (in intercultural dialogue). In order to experience what life in a stilt-house was like, a group may, for example, design an experimental set-up to try and live in such dwellings in the way people did centuries ago. This approach goes beyond digging up artefacts by reconstructing the lived context of such artefacts within our contemporary experience. Thus Goethe writes in the Book of Hafiz, in Imitation:

In deine Reimart hoff ich mich zu finden,

Das Wiederholen soll mir auch gefallen. [17]

In your rhymes' mode myself I hope to find,

The sound reiterated should please me well;

Where experimental archaeology uses reconstruction, Goethe's experimental poetic hermeneutics bridges exteriority through poetic empathy. It could perhaps be described as a non-colonialist, unselfish way of entering the inner centre of an alien world, investing everything one's own world has to offer in an effort to experience, at least through imitatio, that centre as authentically as possible.

For Goethe the poetical encounter is identified with specific tenets of the Mohammedan religion, which his approach allows him to be very precise about: unconditional surrender to the unknowable will of God, serene survey of... earthly concerns, love, suspension between two worlds, all reality cleansed, dissolving symbolically [18] Surrender to the unknowable will of God is mirrored methodologically in symbolic dissolution, which cannot occur without a surrender of the self to the Other.

\section{A long Journey}

Goethe is fully aware that this journey will be a long one. Thus he has at the start of the Diwan the poem Hegire, the French term used in Goethe's day to refer to the hijra or Mahomet's emigration from Mecca to Medina. Goethe, too, embarks upon a journey of emigration, away from everything that has been: The poet sees himself as a traveller. In an instance he has arrived in the orient. He delights in its customs, habits, artefacts, religious attitudes and views, and he does not reject the suspicion that he might be a musulman himself. Goethe experiences this by the strong effect Hafiz's poems had on him:... and I had to respond productively to them for otherwise I would not have been able to withstand its force. Its effect was too powerful... and so I had to find a way of taking part. [19] Thus Goethe writes about this journey: Above all, the author of these poems would like to be considered a traveller, deserving of some credit for taking a sympathetic reading of the unfamiliar, seeking to adopt its language and share its attitudes and customs. He may be forgiven for succeeding only to a certain extent. [20]

Hegire [21]

Nord und West und Süd zersplittern,

Throne bersten, Reiche zittern,

Flüchte $d u$, im reinen Osten

Patriarchenluft zu kosten,

Unter Lieben, Trinken, Singen

Soll dich Chisers Quell verjüngen. [22]

Dort im Reinen und im Rechten

Will ich menschlichen Geschlechten

In des Ursprungs Tiefe dringen,

Wo sie noch von Gott empfingen

Himmelslehr in Erdesprachen

Und sich nicht den Kopf zerbrachen.

Will in Bädern und in Schenken,

Heil'ger Havis dein gedenken;

Wenn den Schleier Liebchen lüftet,

Schüttelnd Ambralocken düftet.

Ja des Dichters Liebeflüstern

Mache selbst die Huris lüstern. [23]

Wollet ihr ihm dies beneiden,

Oder etwa gar verleiten;

Wisset nur, daß Dichterworte

Um des Paradieses Pforte

Immer leise klopfend schweben, sich erbittend ew'ges Leben.

HEJIRA

NORTH and West and South up-breaking!

Thrones are shattering, Empires quaking;

Fly thou to the untroubled East,

There the patriarchs' air to taste!

What with love and wine and song

Chiser's fount will make thee young.

There, 'mid things pure and just and true,

The race of man I would pursue

Back to the well-head primitive,

Where still from God did they receive 
Heavenly lore in earthly speech,

Nor beat the brain to pass their reach....

In bath or inn my thought would be,

Holy Hafiz, still of thee;

Or when the veil a sweetheart lifts

From amber locks in odorous drifts;

Ay, whispered loves of poet fire

Even the Houris to desire!

Would you envy him for this,

Or bring despite upon his bliss,

Know that words of poets rise

To the gate of Paradise,

Hover round, knock light, implore

Heavenly life for evermore. [24]

These lines make clear that the poet is able to reach deeper than thinking alone would allow. In these depths, the poet's words take us to the gates of paradise.

It is not only in the Book of the Cupbearer that Goethe links the exclamation

Hafis o lehre mich,

Wie du's verstanden! [25]

O Hafiz, instruct me,

How seemed it to you?

with enjoyment, especially the enjoyment of drinking:

Und mit diesem Lied und Wendung

Sind wir wieder bei Hafisen,

Denn es ziemt des Tags Vollendung

Mit Genießern zu genießen. [26]

And with such winding of my lay,

Hafiz, once more we hear thy voice;

'Tis meet in each concluded day

With the rejoicing to rejoice.

Poetry thus becomes an imaginative space for exploring intercultural balance, the poetological empathy of world literature becomes a vehicle of intercultural communication.

In his notes to the Book of Love, Goethe characterises this book as lending itself to symbolic digression, which it is hard to resist in the realm of the orient. A great mind, not content with what it is given, considers everything that is presented to the senses a disguise. Behind it, a higher life of the mind is hiding, cheekily and stubbornly, to draw us towards it and lure us up into loftier regions. [27] The image of the disguise is interesting because the same image is conveyed by another text, although using a different play on language: What is called idea: whatever appears and therefore presents to us the law of all that appears. [28] Poetry, then, notwithstanding its diversity, uncovers whatever is disguised and at the same time holds it together within the remit of the poetic mind.

In 1827, Goethe writes: Since many an aspect of our experiences defies straightforward statements and direct communication, I have for a long time been resorting to the method of revealing the deeper meaning to the perceptive reader by means of contrasting structures that are reflected in each other, as it were. [29] Goethe is fascinated by this freedom, achieved through reciprocal reflection.

Something special comes out of Goethe's encounter with Hafiz: it does not revolve any more around the identification of the self in the Other (as a condition of acceptance), but, $a b$ initio, around absolute and unconditional acceptance in a shared poetical space. What is at stake is the freedom of diversity, of spirit and mind that is inherent in this; what is at stake is the process whereby the familiar is let go of, surrendered and offered up for the benefit of the Other, so that a space is opened up and empathy created for the Other within the familiar, allowing the Other to flourish and blossom.

\section{Result}

\section{Removing of boundaries}

The search for deep experiences, analogous to poetry, that transcend boundaries - including boundaries of understanding - has considerable relevance today. We may think for example, of the primary importance of shared everyday experiences with a view to the possibility and the necessary limits of understanding. In a globalised world, everybody will never understand everything, regardless of how many attempts there are at dialogue. Therefore, understanding can never be a precondition of acceptance and peaceful co-existence. The existence even of that which we do not understand must not be threatened. We must practice accepting others as Other! [30]

This kind of behavioural therapy is the complement to analytical therapies in that, through behaviour modification (which may be a prescribed behaviour modification), a modified way of life becomes possible. This is of value especially where there is limited time for taking an in-depth history or where sufficient capacities for working through memories are not available. Putting this in terms of intercultural and inter-religious relations: on the level of social politics, there may not be enough time for getting to know and understanding the other side's history and situation thoroughly; there may be an urgent need to change actual behaviour so that disadvantaged groups are able to survive. Understanding is important and necessary and may help create solidarity; but it must not become a pre-condition of the latter. Even what is not understood can be integrated into mimesis; what is not understood may open up, through mimesis, its own form of experiential knowing. Such interpoetic rapprochement and appropriation will, of course, lead to some degree of relativising - of that which is familiar, but especially of that which, in the horizon creates in/out boundaries and sets down sanctions.

This is a sort of free intellectual trade. [31] Instead, a hybrid is created, bridging contradictions on a new level and making surprising connections. [32] This discovery of interpoetic similarities within cultural and religious differences generates a different understanding of time as well: there is an acceptance of what is ephemeral vis-a-vis what is permanent and of lasting structure. Goethe's piety found much to resonate with in the work of the Persian poet Hafiz (1320-1390): contemplation and worship of God through the countless manifestations and metamorphoses of his creation. [33] In the talismans, at the start of the Diwan, Goethe praises God in his one hundred names. In essence, to Goethe, 
the image of Allah could be linked more firmly with an unencumbered joy of life than the God of Christianity. [34] Thus Goethe assimilates wisdom and insight wherever they present themselves. [35] Goethe's understanding of symbolic language, too, reflects this relationship of God and diversity. In it, an intellectual contemplation occurs wherein the phenomena adopt an allegorical character pointing beyond itself. [36]

While the Diwan's poems do not lose sight of the typical and general, they mark the point at which the entire diversity of phenomena may acquire an allegorical significance, where even the simplest manifestation may carry a symbolic meaning and become transparent to the realm of the mind and the spirit. [37] The phenomena are not the space for, or shadow of, ideas, but they are in themselves the places where the unknowable reveals itself. Through its very diversity, what is manifest is an infinitely effective revelation of that which is infinite, ineffable and unreachable.

\section{Conclusion}

Primary interconnectednesses that bridge differences

During the period of storm and stress (Sturm und Drang period of German literature) great importance was given to the notion that history and nature, including the vital force animating human history, rather than being known, must be felt as creative vitality, and can be understood only once it has been felt and lived. [38] It is through poetry, music and art that such revelations are discovered and made available to experience.

An memorable example is offered by Anke Bosse: the West-Eastern Divan, Daniel Barenboim and Edward Said's orchestra that brings together young musicians from Israel and Palestine. There may be heated discussion there occasionally, but once the leader plays an A, all will tune their instruments accordingly. Joint music-making, rehearsing and performing allow the musicians and the audience to experience a connection for a limited time - the duration of the music. All differences other than musical ones are negated by this connection. Side-stepping and undermining cultural and religious differences, a new experience of community is created in a new and different fourth dimension, so to speak. However, this new aesthetic space in which everybody is held, is bound to come to an end. But the experience gone through will illuminate everyday life and is not easily forgotten, and it may soften many a knee-jerk reaction that may previously have been part of attitudes towards the Other, thus opening up new possibilities. [39] Back in their mutually hostile home countries, many of these musicians have got actively involved in peace activism. [40]

Cultural politics will have to include both: Goethe's path of entering the Other's aesthetic space and losing oneself in it - in the most positive sense of the word - and then gaining oneself in a new and different way (a simple example being mosques and churches opening their doors, inviting people to enter into the space of their respective faiths and experience their aesthetics); as well as Daniel Barenboim's path of discovering and building new shared aesthetic spaces, where differences are transcended on the level of shared experience. These are all spaces which bypass established contrasts but are themselves un-bypassable: on a new level of mutual recognition.

From this perspective, what is needed is a cultural and societal politics of new aesthetic spaces, asking: to what extent do the popular mass media, film and television, theatres and museums, art and music, literature and religion, open up infinitely wide spaces that act as sources of creative imagination? Are they by their nature able to fructify everyday life as well as all the minor and major political decisions in a way that sustains us and facilitates solidarity? In this view, literature, music and art are indeed media, close to what went before, impacting everyday life, offering deep experiences and, therefore, ambivalent and with consequences open to criticism. [41]

Having been deeply influenced by the popular piety I grew up with (in the Frankonia region of Germany) [42], my first visit to a Hindu temple in Pune, India, somehow felt like coming home. I carried a lot of childhood empathy within me in relation to the status and images of saints, the multitude of candles and accompanying smells, and transferring it onto this place came easily to me. It found space to flourish here: in this environment with its many figurines of varying sizes, the many candles, the incense, the piety of the worshippers there and their ways of expressing their admiration and longing. I was especially taken with the elephant-headed Ganesh, a very popular Hindu expression of the divine [43], probably because a little more than thirty years ago a friend had brought a wonderful poster of Ganesh from her journey to India, wishing that his gift of wisdom would stay with me always.

In this context, I found myself thinking about Hermann Hesse. In his Short Biography and the auto-biographical fairy-tale The Childhood of the Magician [44], entitled The Magician [45], he describes a similar experience: I was lucky... in that among the people bringing me up was the god Pan, who sat in my grandfather's glazed cabinet in the form of a small dancing Indian idol. This deity attended to me in my youth, and long before I was able to read and write... it took root in me to such an extent that in later life, every encounter with an Indian or Chinese sage felt like a cominghome. [46] Those who never knew this sort of popular piety in their own environment, and even more so those who sneer at it, will find empathy difficult when it comes to interreligious experiences, or they might look down even more on similar phenomena in other religions. This prevents any transformation of emotions into what is unfamiliar. [47] What is at stake here are not diffuse good feelings but cognitively charged emotions that have a particular direction and are rooted in the body. What a person has experienced and believes, they will feel: it is an entering into the phenomena, an authentic empathetic rapport and emotional concord. The truth of each faith is left untouched and transformed into a symbolic experience that transcends it, or put differently, is turned into a mediating experiential dimension of what sustains all religions: namely, to use 
Dietrich Bonhoeffer's words, to be so wonderfully sheltered by a gracious power.

\section{References}

[1] Delivered in the Department of English Language and Literature - Sultan Qaboos University, 3rd International Conference on Language, Linguistics, Literature and Translation: Connecting the Dots in a Glocalized World, November 3-5 2016, Oman.

[2] Patrick Colm Hogan, The Death of the Goddess: A Poem in Twelve Cantos, Preface.

[3] Christa Knellwolf King in her lecture at the Oman University on $9^{\text {th }}$ February 2016.

[4] See Johann Wolfgang von Goethe, West-östlicher Divan, München 1982, written between 1814 and 1819, English: Johann Wolfgang von Goethe, West-Eastern Divan, translated by Edward Dowden, London und Toronto 1914.

[5] Johann Wolfgang von Goethe, Klaus-Detlef Müller, Aus meinem Leben, Dichtung und Wahrheit, Text und Kommentar (3. Teil, 14. Buch, 1814), Frankfurt a. M. 1986, 685.

[6] Ibd. 685 und 687.

[7] Vgl. Gerhard Sauder (Hg.), Theorie der Empfindsamkeit und der Sturm und Drang, Stuttgart 2003.

[8] Johann Wolfgang von Goethe, Mahomet, Fragment (1772), in: Gerhard Sauder (Hg.), Johann Wolfgang von Goethe. Sämtliche Werke nach Epochen seines Schaffens, Band 1.1, Der junge Goethe 1757 - 1775, München 1985, 517.

[9] Kommentar zu Mahomet, Fragment, Text und Kommentar, in: Sauder (Hg.), Der junge Goethe 941.

[10] Cf. Goethe, Mahomet 518-519.

[11] Mahomet, Kommentar 943.

[12] Cf. ibid. 943.

[13] Cf. Katharina Mommsen, Goethe und die Arabische Welt, Frankfurt a. M. 1988, 194-238; id., Goethe und der Islam, Frankfurt a. M., Leipzig 2001, 31-95.

[14] Karl Otto Conrady, Goethe. Leben und Werk, Frankfurt am Main 1987, II, 390.

[15] Goethe, westöstlicher Divan, Besserem Verständnis,(Übersetzungen 1819), in: Goethe, Divan (Reclam) 280.

[16] For this see also the translation theory of Rudolf Pannwitz and Walter Benjamin (Illuminationen, Frankfurt am Main 1977, 59ff.), see also from the perspective of an intercultural conceptualisation of a diachronous hemerneutics between the Bible and the present: Ottmar Fuchs, Praktische Hermeneutik der Heiligen Schrift, Stuttgart 2004, $318 \mathrm{ff}$.

[17] Goethe, Divan 21-22.

[18] Goethe in a letter to Zelter 11.5.1820, quotet in den Anmerkungen zu Johann Wolfgang von Goethe, Westöstlicher Divan, München 1982, 134.

[19] Goethe in his announcement of the Divan, Morgenblatt 1816, quoted in: Goethe, Divan, Anmerkungen 136. And: Goethe in a letter to Cotta vom 16.5.1815, quoted in Goethe, Divan, Anmerkungen 133.

[20] Goethe, Besserem Verständnis (Einleitung 1819).

[21] Goethe, Divan 5-6.

[22] Chiser is the keeper of the source of life.

[23] The Huris are the beautiful-eyed playmates of the blessed in paradise.

[24] Written 24th December 1814.

[25] Im Schenkenbuch, ibd. 86

[26] Im Buch des Sängers, Goethe, Divan 13.

[27] Quoted by Goethe, Divan, Anmerkungen 139.

[28] Goethe in den Maximen und Reflexionen Nr. 1136, see Goethe, Divan, Anmerkungen 142.

[29] Goethe in a letter to the Orientalist Iken vom 27.9.1827, see Goethe, Divan, Anmerkungen 134.

[30] Ulrike Bechmann, Besprechung von Kuschel, Karl-Josef: Juden-Christen-Muslime, in: Theologische Revue 105 (2009) 4, 342-348, 347.

[31] Goethe to Carlyle VII.

[32] There are other texts by Goethe that show the same tendency to disassemble the boundaries of national literature and relate it to world literature. For example, he was not content with a national library limited to the German language. In 1808, he requested the following changes: indeed, one would have to explicitly point out the achievements of other nations, not least because the books is intended for children, too, and especially in this day and age they have to be made aware of the achievements of other nations. Quoted in Conrady, Goethe II, 499. What is important for Goethe here is not only that which relates to the familiar, but that which contradicts it:... thus it is to be expected that every (nation) will find in another something acceptable and something revolting, something worth copying and something to be avoided. Quoted from Thomas Carlyle, Leben Schillers, Entwurf; 12, 364, in Conrady II, 500.

[33] Conrady, Goethe II, 402.

[34] Ibid. 402.

[35] Ibid. 402.

[36] Ibid. 403.

[37] Ibid. 404.

[38] Rüdiger Safranski, Schiller oder Die Erfindung des Deutschen Idealismus, München, Wien 2/2008, 50.

[39] See Anke Bosse, Interkulturelle Balance statt clash of cultures. $\mathrm{Zu}$ Goethes West-östlichem Divan, in: Etudes germaniques 60 (2005) 2, 231-248, 244.

[40] On July 7, 2001, Daniel Barenboim conducted Richard Wagner for the first time publicly in Israel. This reflects a difficult and oft-criticised attempt at rehabilitating Wagner and his music to create community and avoid remaining fixated on how he was instrumentalised by national socialism to make the horror of exclusion and destruction aesthetically representable. 
[41] Cf. Ottmar Fuchs, Die Menschen in ihren Erfahrungen suchen, in: Rainer Bucher/Ottmar Fuchs/Joachim Kügler (Hg.), In Würde leben, Luzern 1998, 209-334; Wolfgang Welsch, Grenzgänge der Ästhetik, Stuttgart 1996.

[42] Cf. Rainer Bucher, Rainer Krockauer, Es geht nichts verloren, Würzburg 2010, 149-165.

[43] Cf. Anneliese und Peter Keilhauer, Die Bildsprache des Hinduismus. Die indische Götterwelt und ihre Symbolik, Köln 3/1990.
[44] See Hermann Hesse, Kindheit des Zauberers, Frankfurt am Main 1974.

[45] Hermann Hesse, Sämtliche Werke, Band 12, Autobiographische Schriften, Berlin 2003, 23-45.

[46] Ibid. 23.

[47] Cf. Dominik Perler, Transformationen der Gefühle. Philosophische Emotionstheorien 1270-1670, Frankfurt a. M. 2011. 